\title{
Summary of Research on Inter-Organizational Relationship Risk and Knowledge Sharing in Green Supply Chains
}

\author{
Li Zhang \\ Jinling Institute of Technology, Nanjing 211169, China \\ nj.teacher@163.com
}

\begin{abstract}
Under the macro environment of "greening" of the world economy, it is of positive practical significance to effectively identify and reduce the Inter-Organizational relationship risk of green supply chain based on the national green development strategy to build Inter-Organizational relationship based on trust. The paper discusses the connotation of green supply chain knowledge sharing, the influencing factors of green supply chain knowledge sharing, the risk of green supply chain Inter-Organizational relationship, and the operation mechanism of green supply chain InterOrganizational relationship risk, and provides an outlook on the future research trends. From the current situation, future research should integrate multidisciplinary knowledge system and use a combination of qualitative and quantitative methods to explore the relationship between InterOrganizational relationship risk and knowledge sharing of green supply chain, to promote the depth and further development of green supply chain research.
\end{abstract}

Keywords: Green Supply Chain; Relationship Risk; Knowledge Sharing.

\section{Introduction}

With the increasing awareness of environmental protection, resource conservation and the concept of sustainable development that takes into account social, economic and ecological aspects, the concept of low carbon economy and green effect has been introduced into the supply chain, and green supply chain has gradually become the inevitable development of the world economy [1].

Due to the "greenness" of green products and the heterogeneity of knowledge and highly complementary business among supply chain members, only with the support of corresponding technology and knowledge can the "greening" activities be carried out smoothly and the goal of green supply chain management be realized. The goal of green supply chain management can be realized. Knowledge sharing among supply chain node enterprises can effectively transfer and integrate green knowledge resources, accelerate the speed of green knowledge innovation and improve the performance of green knowledge innovation. Under this circumstance, the knowledge sharing mechanism among green supply chain enterprises and how to improve its efficiency and effectiveness become a priority issue for enterprises.

Cooperation among green supply chain enterprises is characterized by a typical implicit agreement and is essentially a competitive relationship. In such a background, the process of cooperation among green supply chain organizations is accompanied by potential relationship risks such as moral risks, information asymmetry and destructive conflicts. In order to prevent opportunistic behaviors and dedicated knowledge from being imitated and learned in the process of knowledge sharing, green supply chain enterprises generally adopt the behavior of knowledge protection to safeguard their legitimate interests, which objectively increases the difficulty of knowledge sharing among green supply chain enterprises. The knowledge sharing among green supply chain enterprises directly affects whether the goal of green supply chain management can be achieved.

\section{Study on Connotation of Inter-Organizational Relationship Risk in Green Supply Chain}

Green Supply Chain (GSC) is based on the supply chain. Under the benefit-driven situation of cost reduction and risk sharing, it is linked by various contracts or agreements to achieve the triple objectives of economic development, environmental protection and resource saving. As a special 
form of strategic alliance, green supply chain inevitably faces uncertainties and potential risks from the future behavior of supply chain members during its operation.

Table 1. Summary of Relationship Risk Concepts

\begin{tabular}{|c|c|c|}
\hline Author & Concept & Key Elements \\
\hline $\begin{array}{l}\text { Das and Teng } \\
(1996,2001)\end{array}$ & $\begin{array}{c}\text { Potential for non-compliance with the spirit of cooperation } \\
\text { related to the partnership or by the partner and uncertainty about } \\
\text { the existence of the desired partnership due to opportunistic } \\
\text { behavior }\end{array}$ & $\begin{array}{l}\text { Potentiality, } \\
\text { uncertainty }\end{array}$ \\
\hline $\begin{array}{c}\text { Nooteboom et al. } \\
\text { (1997) }\end{array}$ & Outcomes and losses of opportunistic behavior of partners & Outcomes or losses \\
\hline Helene (2014) & $\begin{array}{l}\text { Complex function of uncertainty about partners' future behavior } \\
\text { and the absence of power to ensure promise fulfillment }\end{array}$ & $\begin{array}{l}\text { Uncertainty, absence, } \\
\text { and complex } \\
\text { functions }\end{array}$ \\
\hline Rui Xu (2015) & $\begin{array}{r}\text { Likelihood and outcomes of u } \\
\text { knowledge sharing a }\end{array}$ & $\begin{array}{r}\text { Likelih } \\
\text { outc }\end{array}$ \\
\hline Qi'an Lu (2016) & $\begin{array}{l}\text { Collaborators do not fulfill alliance commitments and may act } \\
\text { opportunistically, thus making the alliance potentially damaging }\end{array}$ & Damage \\
\hline $\begin{array}{l}\text { Feiqiong Chen and } \\
\text { Xudan Yu (2010) }\end{array}$ & $\begin{array}{l}\text { Potential loss due to possible opportunistic behavior of alliance } \\
\text { partners or lack of loyalty to the alliance }\end{array}$ & Potential damage \\
\hline $\begin{array}{l}\text { Cheng and Sheu } \\
\text { (2011) }\end{array}$ & Conflict and loss of interorganizational cooperation & Conflict and loss \\
\hline Linlin Jiang (2011) & $\begin{array}{l}\text { Risks arising from the existence of cooperative relationships } \\
\text { between the subjects of the alliance }\end{array}$ & $\begin{array}{l}\text { Generation of } \\
\text { cooperation } \\
\text { relationship }\end{array}$ \\
\hline
\end{tabular}

Source: Compiled by the author

The traditional view attributes risk to an unanticipated change as well as negative change, which is expressed as unpredictable variables or losses [2]. As early as 1994, foreign scholars Ring and Vanden ven pointed out that risk involves both future development state and future cooperationrelated aspects. Cooperation-related risk refers broadly to losses resulting from partners' breach of agreed commitments. In the current ultra-competitive environment, green supply chain intercompany cooperation emphasizes and pursues long-term and direct cooperation, stresses the ability to solve problems and plan together, and pays more attention to Inter-Organizational trust and cooperation, which is very different from the traditional supply chain cooperation relationship [3]. Due to Inter-Organizational differences and conflicts such as information asymmetry, opportunism, and organizational culture among green supply chain partners, green supply chain cooperation faces relationship risks arising from uncertainty of future behavior of partners and power asymmetry (as shown in Table 2.1). According to Das and Teng (1996, 2001), relationship risk can be understood as the potential associated with the partnership or for partners' non-compliance with the spirit of cooperation and the uncertainty of the opportunistic behavior leading to the desired partnership. According to Cheng and Sheu (2006), relationship risk is the conflict and loss of interorganizational cooperation caused by opportunistic behavior and power asymmetry[4]. According to Feiqiong Chen and Xudan Yu (2010), relationship risk in corporate alliances refers specifically to the potential loss due to possible opportunistic behavior of alliance partners or lack of loyalty to the alliance[5]. Linlin Jiang (2011) argues that the risks arising from the existence of cooperative relationships among alliance players are all relational risks [6]. 


\section{Study on Operation Mechanism of Inter-Organizational Relationship Risk in Green Supply Chain}

\subsection{The Analysis of Inter-Organizational Relationship Risk from the Perspective of Resource- based Theory}

According to the viewpoint of Resource-based theory, resource attributes determine the characteristics and management of risk. In order to obtain key resources that are not available within the organization, green supply chain member companies enhance the dependence of external organizations on themselves and reduce their own dependence on external companies, thus generating resource dependence in green supply chain Inter-Organizational relationships (Inkpen, 1998). In order to protect the value of their own resources and inimitability, the partners inevitably adopt protective behaviors, resulting in the risk of Inter-Organizational relationship between green supply chain organizations.

\subsection{Analysis of Inter-Organizational Relationship Risk from the Perspective of Transaction Cost Theory}

According to the viewpoint of transaction cost theory, any organization aims at self-interest, and as long as there is an opportunity, they will carry out opportunistic behavior and cause relationship risk (Williamson, 1985). According to the above view, we can argue that the relationship risk among green supply chain organizations arises due to cooperation with each other and has typical endogenous properties. In order to gain self-interest, the member companies of green supply chain alliance may distort, hide, transform information and conceal poor quality work among the companies involved in green supply chain cooperation. When the self-interest of enterprises involved in green supply chain cooperation is greater than the cooperation interest, they have the tendency to betray the green supply chain strategic alliance, and when this tendency is executed, the relationship risk emerges.

\subsection{Analysis of Inter-Organizational Relationship Risk from the Perspective of Decision Theory School}

The decision-theoretic school of thought believes that individuals act rationally to satisfy preferences and maximize utility. Green supply chain cooperation depends on the interpretation of the external environment by the decision makers of each participant in the green supply chain alliance, and thus the importance of the ability of the decision makers of each participant to identify the alliance risks and the personal characteristics of the top management of the company in the process of participating in the green supply chain strategic alliance are crucial to the influence of the decision of the company's participation in the green supply chain strategic alliance strategy (Das and Teng, 2011). When unrealistic goal expectations in green supply chain strategic alliances and incompatibility with green supply chain partners' goals can cause Inter-Organizational conflicts between the two parties, the alliance members will act opportunistically due to lack of patience and trust and then lead to InterOrganizational relationship risks.

\subsection{The Analysis of Inter-Organizational Relationship Risk from the Perspective of Game Theory}

The theoretical perspective of game theory suggests that each stage of development of cooperation of participating members of strategic alliances has interests oriented towards each other that deviate from the overall system and rules of the alliance, and that strategic alliances fail not due to managers' wrong alliance decisions, but due to the nature of the incentive structure of the prisoner's dilemma [7] (Parkhe, 1993; Zhao and Gareth et al., 2015). Each stage of green supply chain alliance development is fully consistent with the theoretical perspective of game theory, where the risk of the relationship between members of a green supply chain alliance depends on the payment function of both parties. 


\section{Study on Connotation of Knowledge Sharing in Green Supply Chain}

Effective knowledge sharing can lead partners to form a linear flow of resources, information, and products in the chain across organizational boundary barriers, which then results in agility, adaptability, and predictability of supply chain cooperation (Shih, Hsu, and Balasubranian, 2012) [8]. Green supply chain knowledge sharing involves the act of transferring and disseminating value-based knowledge from manufacturing companies to partners, and by sharing value-based knowledge with companies in the green supply chain (e.g., suppliers or undertakers, etc.), manufacturing companies acquire new capabilities and discover new opportunities[9] (Cheng, 2011). Therefore, knowledge sharing in green supply chain refers to the knowledge interaction behavior of transferring from high knowledge potential position to low knowledge potential receptor by node enterprises in the supply chain with knowledge innovation as the driving force to realize sustainable green economy in the supply chain, sharing key elements such as value-based resources, information and knowledge with each other to realize effective complementation and integration of green supply chain knowledge. The knowledge sharing of green supply chain promotes the formation of an intermediate organization in the form of knowledge community proposed by "Burkat Holzner" among the member enterprises in the alliance, in which the core enterprises take the lead, absorb and gather other enterprises in the chain (including suppliers, manufacturers, investors and partners, etc.) to carry out "green" knowledge innovation activities, and through a certain degree of cooperation between the core enterprises and the partners, the core enterprises will be able to develop the "green" knowledge innovation activities. The "green" knowledge innovation activities are carried out by the core enterprises, and the open innovation of knowledge is realized through certain organizational structure and rules[10] (Wei Wang and Min Luo, 2020). The member enterprises in the chain create and maintain a kind of knowledge chain aggregate through knowledge sharing, improve the allocation efficiency of value-based resources in the supply chain alliance through cooperative innovation, reduce the overall pollutant emission level of the supply chain, and then achieve the strategic goal of green supply chain management [11].

\section{Study on Influencing Factors of Green Supply Chain Knowledge Sharing}

The member enterprises of green supply chain alliance form a knowledge aggregate that aggregates multiple subjects, levels and elements, and there are multidimensional and dynamic complex relationships and many information exchange and feedback mechanisms between crossorganizations, which directly affect the efficiency and effectiveness of knowledge sharing among green supply chain organizations. Based on the previous results and combined with the unique characteristics of green supply chain alliance cooperation, the study summarizes the influencing factors of green supply chain knowledge sharing into four aspects, namely innovation drive, knowledge attributes, sharing environment and absorption capacity.

(1) Innovation drive. Complementary resources and information sharing are the inevitable choices for green supply chain alliances to achieve green innovation. The main driving force for knowledge sharing among green supply chain organizations is the innovation drive to achieve greenness in the supply chain, especially the green technology innovation and sharing that are closely related to the low-carbon concept and environment-friendly awareness. Cooperative innovation among green supply chain organizations is a learning process that gives full play to exploratory and excavative organizational learning to acquire valuable information and resources and realize smooth interaction of technology and knowledge in the chain.

(2) Knowledge attributes. The knowledge attributes among different subjects of green supply chain alliance directly determine whether knowledge sharing can be carried out smoothly. Knowledge attributes are expressed as the characteristics of knowledge such as implicit, expressibility, observability, embeddedness and specialization. Based on the classification of different descriptions of knowledge, knowledge is divided into explicit knowledge and tacit knowledge. Explicit knowledge can be expressed in an explicitly coded form, while tacit knowledge is ambiguous and difficult to 
express through language and to obtain through simple observation. Research suggests that tacit knowledge is difficult to teach and learn, more difficult to transfer, and requires sustained joint learning by both partners to master (Kogut and Zander, 1995)[12].

(3) Shared environment. The sharing environment mainly refers to the longitudinal development of Inter-Organizational relationship of green supply chain alliance, and good Inter-Organizational relationship can create a basic platform for knowledge sharing. The level of trust is not only the basis of cross-organizational cooperation, but also a sufficient necessary condition for knowledge sharing in supply chain alliances. The higher the level of trust, the easier the knowledge sharing among member enterprises of green supply chain alliances can be realized. The higher the trust level is, the easier the knowledge sharing among the members of green supply chain alliance will be realized. The good development of Inter-Organizational relationship of green supply chain can effectively promote the knowledge flow behavior of the supply chain as a whole and deepen the speed and depth of knowledge transfer between cross-organizations. It realizes the competitive advantage of itself by using the Inter-Organizational relationship resources of supply chain partners through the "leverage principle".

(4) Absorptive capacity. Absorptive capacity is a concept of behavioral dimension, which refers to the ability to recognize the value of new knowledge, assimilate it and apply it to business purposes. Absorptive capacity includes the ability of knowledge acquisition and assimilation, and the ability of knowledge transformation and utilization. Knowledge sharing in green supply chain is an intensive activity of mutual learning and continuous absorption of knowledge among enterprises in the chain. Knowledge can only be considered as quality and quantity knowledge sharing if it is learned and understood by the recipient and assimilated and utilized. The knowledge absorption capacity is limited by the learning ability and a priori knowledge of green supply chain alliance partners. For partners with strong learning ability and high-level priori knowledge, the stronger the knowledge absorption capacity is, the more efficient and effective the green supply chain knowledge sharing will be.

\section{Research Trends}

From the existing literature, although knowledge sharing is considered as one of the key elements to achieve the goal of green supply chain management, the research on the influence relationship of knowledge sharing in green supply chain from the perspective of Inter-Organizational relationship risk is relatively rare. Through the above literature review of green supply chain related research, we can easily find some patterns as follows.

(1) From the theoretical level, most of the studies in the literature are qualitative studies based on the connotation, characteristics, operation mode, risk management and performance evaluation of the green supply chain itself, and empirical studies are rare. In addition, the current green supply chain studies are mainly based on performance evaluation, but less on knowledge management in the green supply chain from the perspective of influence mechanism.

(2) From the level of mechanism of action and mechanism of influence, the academic and practical circles have recognized the important role played by knowledge in green supply chain. The existing relevant studies have generally adopted the research framework and logical structure based on knowledge theory, focusing on analyzing the operation mechanism of knowledge transfer and knowledge innovation in green supply chain, the influencing factors and the transfer process among different green supply chain enterprise subjects and green supply chain alliances. Thanks to the crossorganizational characteristics of their cooperation, the relationship risk among green supply chain partners, as an important influencing factor, must play an important influencing role.

(3) From the current research on green supply chain from the perspective of knowledge, it is not difficult to find that scholars coincidentally focus on the analysis of knowledge management mode and operation mechanism, but they ignore the cross-organizational characteristics of green supply chain cooperation. Although some scholars have begun to pay attention to the influence of external 
influencing factors on the knowledge sharing of green supply chain, the degree of attention is seriously insufficient. The knowledge sharing of green supply chain is largely influenced by the InterOrganizational relationship, while there is a lack of examples of survey data from the enterprise level for standardized research. In the future, the knowledge systems of multiple disciplines such as industrial economics, management science, science and technology should be integrated, and the relationship between the risk of Inter-Organizational relationship and the influence of knowledge sharing of green supply chain should be explored by using statistical techniques, mathematical modeling, system simulation and other quantitative methods research to promote the depth and further development of green supply chain research.

\section{Acknowledgments}

[Funded Project] This paper is the result of the project of the Humanities and Social Sciences Research Planning Fund of the Ministry of Education of China, "Research on the Optimization of Logistics System and Transformation and Upgrading in the Context of 'the Belt and Road Initiative"" (17YJA790027).

\section{References}

[1] "A framework for integrated risk management in international business". Journal of International Business Studies, 1992, 23(2): pp. 311-331.

[2] Helene Delerue. "Relational Risks Perception in European Biotechnology Alliances: The Effect of Contextual Factors" [J]. European Management Journal, 2018, 5(22): pp. 546-556.

[3] Jao-Hong Cheng. "Inter-Organizational relationships and knowledge sharing in green supply chainsmoderating by relational benefits and guanxi" [J]. Transportation Research, 2019, Part E(47): pp. 837849.

[4] Qi'an Lu. "Research on Risk of Strategic Alliance and Its Management" [J]. Journal of Guangxi Normal University: Philosophy and Social Science Edition, 2016, 42(3): pp. 16-19.

[5] Annie H. Liu, Albert Noel Gould, Minna Rollins, Hongzhi Gao. "Role conflict and ambiguity confronting transnational business networkers: Contrasting social stigma and relational risks for Chinese and Western boundary spanners" [J]. Industrial Marketing Management, 2014, 6(43): pp. 911-919.

[6] Rui Zhao, Gareth Neighbour, Jiaojie Han, Michael McGuire, Pauline Deutz. "Using game theory to describe strategy selection for environmental risk and carbon emissions reduction in the green supply chain" [J]. Journal of Loss Prevention in the Process Industries, 2012, 6(25): pp. 927-936.

[7] Helene delerue. "Relational risk perception and alliance management in French biotechnology SMEs" [J]. European Business Review, 2005, 17(6), pp. 532-546.

[8] Zhu, Q., Sarkis, J. “The moderating effects of institutional pressures on emergent green supply chain practices and performance" [J]. International Journal of Production Research, 2007, 45(18-19): pp. 43334355.

[9] Cheng, J. H. "Inter-Organizational relationships and information sharing in supply chains" [J]. International Journal of Information Management, 2011, 31: pp. 374-384.

[10] Ju Wang, Min Luo. "Construction of Knowledge Community: Discussion Based on Rules and Structures" [J]. China Industrial Economics 2007, 4: pp. 54-62.

[11] Panteli, N., Sockalingam, S. "Trust and conflict within virtual Inter-Organizational alliances: a framework for facilitating knowledge sharing" [J]. Decision Support Systems, 2020. 39(4): pp. 599-617.

[12] Kogut B., Zander U. "Knowledge of the firm, combinative capabilities and the replication of technology" [J]. Organization Science, 2020, 3: pp. 383-397. 